\title{
Clinical distribution and antibiotic sensitivities of staphylococcal strains isolated over an eight-month period
}

\author{
PE VARALDO, O SORO, G GRAZI, AND F BIAVASCO \\ From the Institute of Microbiology, University of Genoa Medical School, Genoa, Italy
}

SUMMARY A total of 842 staphylococci isolated from clinical material over an eight-month period and regarded as probable pathogens were identified according to lyogroup. Almost half the isolates belonged to lyogroups other than lyogroup I (Staphylococcus aureus), suggesting that coagulasenegative staphylococci are increasingly involved in human infections. All isolates were tested for sensitivity to 12 antibiotics. A greater resistance was observed in non-lyogroup I isolates, which again suggests a pathogenic significance of coagulase-negative staphylococci. Only lyogroup I strains, however, were obtained more frequently from clinical isolates than from healthy human skin. The distribution of the isolates in each lyogroup according to their clinical source is reported.

The significance and frequency of isolation of the different staphylococcal species from clinical sources has not been fully investigated to date. Only some specific aspects have been studied, such as the association of coagulase-negative staphylococci with urinary tract infections. ${ }^{1-9}$ The lack of more comprehensive studies makes it difficult to evaluate the pathogenicity of the different staphylococcal species currently recognised.

In our laboratory, staphylococci are usually identified according to their lytic activity patterns. In previous studies, the type of lytic activity displayed by staphylococcal strains has been shown to have a high discriminatory power and taxonomic value within this bacterial genus. ${ }^{10-14}$ Six 'lyogroups' of human staphylococci identified according to their lytic activity patterns correlated well with human staphylococcal species recognised and identified according to wholly different criteria. ${ }^{11} 12$ Given such close relationships, it makes no substantial difference whether clinical staphylococcal isolates are identified according to lyogroup or to species. Both procedures have a similar aim and provide a similar amount of diagnostic information.

In this study lyogroup identification was performed according to a simplified system; its advantages with respect to other methods designed for routine identification of staphylococci have been shown in a comparative investigation. ${ }^{15}$

Accepted for publication 6 August 1980

\section{Material and methods}

BACTERIAL STRAINS

A total of 842 staphylococci, all Gram-positive and catalase-positive cocci and belonging to the genus staphylococcus, ${ }^{15} 16$ were isolated from a variety of clinical specimens processed in our Institute's diagnostic laboratory over an eight-month period. All specimens were from inpatients in various clinical departments of the University of Genoa Medical School. Many more staphylococci than the number reported above were isolated during the eight-month study period, but those isolates thought not to have clinical relevance were disregarded. Several parameters were considered in evaluating whether the isolates were to be regarded as clinically relevant saprophytic organisms or contaminants. Such parameters included the nature of the specimen, the procedure of specimen collection, the quantitative amount of colony-forming units yielded by the culture, the association (regarded both quantitatively and qualitatively) with other organisms in mixed cultures, relation to the patient's condition and symptoms, and repeated isolation from consecutive specimens.

ROUTINE LYOGROUP IDENTIFICATION A simplified lyogroup identification system was used. ${ }^{15}$ Preparation and inoculation of the test media, determination of lytic activity pattern and phosphatase activity, and the resulting lyogroup identi- 
fication were carried out according to previously described procedures. ${ }^{15-17}$

\section{ANTIBIOTIC SENSITIVITY TESTING}

The sensitivity of the isolates to 12 antimicrobial agents was determined using the standard agar diffusion method. Plates of DST agar (Oxoid) supplemented with $5 \%$ defibrinated horse blood were inoculated with suitably diluted broth cultures in order to obtain a just confluent growth after incubation. Antibiotic-impregnated discs were applied to the surface of the inoculated plates using a 12-disc dispenser. After overnight incubation at $37^{\circ} \mathrm{C}$ the plates were examined, and the diameters of the inhibition zones were measured to determine antibiotic sensitivities. When intermediate zone sizes were observed, that is, halfway between sensitive and resistant, the strains were recorded as resistant. The 12 antibiotics tested and the respective contents of the discs used were as follows: penicillin G (10 units), oxacillin $(1 \mu \mathrm{g})$, methicillin $(5 \mu \mathrm{g})$, cephalothin $(30 \mu \mathrm{g})$, fosfomycin $(50 \mu \mathrm{g})$, tetracycline (30 $\mu \mathrm{g})$, chloramphenicol $(30 \mu \mathrm{g})$, erythromycin $(15 \mu \mathrm{g})$, lincomycin $(2 \mu \mathrm{g})$, gentamicin $(10 \mu \mathrm{g})$, nitrofurantoin $(100 \mu \mathrm{g})$, and co-trimoxazole (sulphamethoxazole $23.75 \mu \mathrm{g}+$ trimethoprim $1.25 \mu \mathrm{g}$ ). Discs were obtained from BBL, Cockeysville, Md, USA, except for fosfomycin, which was obtained from Italchemi $\mathrm{SpA}$, Parma, Italy.

\section{Results}

All the clinical isolates of staphylococcus were identified using the simplified lyogroup system. ${ }^{15} \mathrm{With}$ the exception of seven strains whose lyogroup could not be determined, all other isolates were identified as belonging to one of the six known lyogroups of human staphylococci. The total number and percentage of staphylococci in each lyogroup are shown in Table 1 together with previously established relationships between staphylococcal lyogroups and species. ${ }^{12} 15$ Over half of the isolates $(52 \%)$ were members of lyogroup I. Among the other staphylococci, strains of lyogroup V $(25 \%)$ and lyogroup VI (13\%) predominated. There were fewer isolates in lyogroup IV $(6 \%)$, lyogroup II $(2 \%)$, and lyogroup III ( $1 \%)$.

Table 1 Lyogroup distribution of 842 clinical isolates of staphylococcus

\begin{tabular}{|c|c|c|c|}
\hline Lyogroup & Related species & $\begin{array}{l}\text { No. of } \\
\text { isolates }\end{array}$ & $\%$ \\
\hline I & Staph. aureus & 436 & 52 \\
\hline il & Staph. simulans & 16 & 2 \\
\hline \multirow[b]{2}{*}{ IV } & Staph. capitis & 11 & 1 \\
\hline & $\begin{array}{l}\text { Staph. saprophyticus, Staph. cohnii, } \\
\text { Staph. xylosus }\end{array}$ & 48 & 6 \\
\hline V & Staph. epidermidis & 214 & 25 \\
\hline VI & $\begin{array}{l}\text { Staph. hominis, Staph. haemolytıcus, } \\
\text { Staph. warneri }\end{array}$ & 110 & 13 \\
\hline \multicolumn{2}{|c|}{ Unidentified } & 7 & 1 \\
\hline
\end{tabular}

In Table 2 the isolates are listed according to lyogroup and clinical source. The largest number of clinically relevant staphylococci were obtained from wounds and abscesses $(23 \%)$, urine $(12 \%)$, throat

Table 2 Distribution of 842 staphylococcal isolates according to lyogroup and clinical source

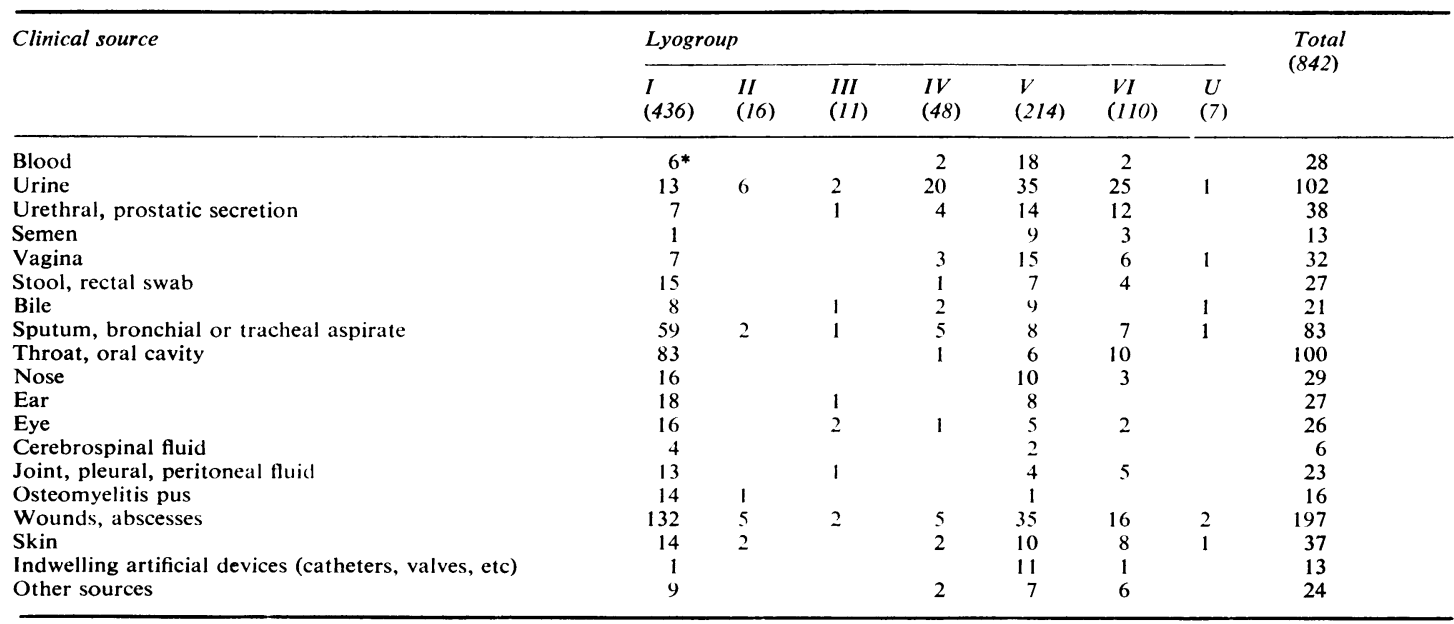

$\mathbf{U}=$ unidentified.

Numbers in parentheses indicate number of isolates in each group.

*Data are given as numbers of isolates. 
and oral swabs $(12 \%)$, and respiratory secretions $(10 \%)$.

The patterns of antimicrobial resistance of the strains of each lyogroup to 12 antibiotics are shown in Table 3. A total of $11 \%$ of all isolates were sensitive to all antibiotics tested; five (1\%) were resistant to gentamicin, $16(2 \%)$ to cephalothin, and $24(3 \%)$ to nitrofurantoin. Increasing rates of resistance were obtained for chloramphenicol $(7 \%)$, co-trimoxazole $(10 \%)$, lincomycin $(13 \%)$, erythromycin $(14 \%)$, methicillin $(14 \%)$, oxacillin $(22 \%)$, fosfomycin $(26 \%)$, and tetracycline $(31 \%)$. The highest rate of resistance was to penicillin $(65 \%)$.

\section{Discussion}

Lyogroup I (Staphylococcus aureus) was found to predominate among the clinical isolates of staphylococcus, but not to the extent that one might expect in view of the conventional idea that coagulasenegative staphylococci are less pathogenic. Although the actual clinical relevance of a staphylococcal isolate is sometimes difficult to substantiate, even when rigorous criteria are applied, the fact that almost half of the staphylococci isolated from clinical material over an eight-month period and regarded as likely pathogens were not Staph. aureus is one crucial aspect of this study. Similar ratios of Staph. aureus to non-Staph. aureus clinical isolates have been reported in other surveys. ${ }^{18}{ }^{19}$ It should be noted, however, that, with the exception of lyogroupI, the distribution among the different lyogroups of the clinical staphylococcal isolates was similar to that of the average staphylococcal flora of healthy human $\operatorname{skin}^{2021}$ (and unpublished results). This indicates that Staph. aureus has a special ability to overcome host defences, whereas other staphylococci are less able to do so and do not show particular differences from one lyogroup (or species) to another.

As for lyogroup distribution according to clinical material, the prevalence of lyogroup I from most sources and of lyogroup $\mathrm{V}$ from blood, genital secretions, or indwelling artificial devices is in agreement with what has been reported for Staph. aureus and Staphylococcus epidermidis in previous surveys. ${ }^{18} 19$ 22-24 Our findings regarding urinary isolates, on the other hand, differ from other reports. We did not find the predominance of novobiocinresistant staphylococci (Staphylococcus saprophyticus, above all) reported by several authors. ${ }^{5-7} 25-29$ In our study, lyogroup IV strains-those overlapping with novobiocin-resistant staphylococci-were isolated in larger numbers from urine than from other specimens, but their frequency among urinary isolates was lower than that of lyogroup $\mathrm{V}$ and lyogroup VI strains. It should be noted also that in another recent report ${ }^{9}$ Staph. saprophyticus strains (or more generally novobiocin-resistant staphylococci) were not the most common cause of staphylococcal infections of the urinary tract. This is probably due to the fact that the specimens examined in our study were from inpatients of both sexes and all ages, whereas Staph. saprophyticus has been described as a cause of urinary infections virtually confined to young female outpatients. ${ }^{5-7} 26$

Our findings regarding the antibiotic sensitivity of clinical staphylococcal isolates agree with the current view that coagulase-negative staphylococci tend to become more resistant than their coagulasepositive counterparts. ${ }^{9} 3031$ This stresses the pathological importance of coagulase-negative staphylococci and also suggests that their involvement in human infections is likely to increase. In our investigation, for 10 of the antibiotics tested the

Table 3 Antibiotic resistance of 842 clinical staphylococcal isolates identified according to lyogroup

\begin{tabular}{|c|c|c|c|c|c|c|c|c|c|c|c|c|c|c|c|c|c|c|}
\hline \multirow{3}{*}{$\begin{array}{l}\text { Antimicrobial } \\
\text { agents }\end{array}$} & \multicolumn{14}{|c|}{ Lyogroup } & \multirow{2}{*}{\multicolumn{2}{|c|}{$\begin{array}{l}\text { Total non- } \\
\text { lyogroup I } \\
\text { isolates } \\
(406)\end{array}$}} & \multirow{2}{*}{\multicolumn{2}{|c|}{$\begin{array}{l}\text { Total } \\
\text { isolates } \\
(842)\end{array}$}} \\
\hline & \multicolumn{2}{|c|}{$\begin{array}{l}I \\
(436)\end{array}$} & \multicolumn{2}{|l|}{$\begin{array}{l}I I \\
(16)\end{array}$} & \multicolumn{2}{|l|}{$\begin{array}{l}I I I \\
(I I)\end{array}$} & \multicolumn{2}{|l|}{$\begin{array}{l}I V \\
(48)\end{array}$} & \multicolumn{2}{|l|}{$\begin{array}{l}V \\
(214)\end{array}$} & \multicolumn{2}{|c|}{$\begin{array}{l}V I \\
(110)\end{array}$} & \multicolumn{2}{|l|}{$\begin{array}{l}U \\
(7)\end{array}$} & & & & \\
\hline & No. & $\%$ & No. & $\%$ & No. & $\%$ & No. & $\%$ & No. & $\%$ & No. & $\%$ & No. & $\%$ & No. & $\%$ & No. & $\%$ \\
\hline Penicillin G & 314 & 72 & 8 & 50 & 3 & 27 & 8 & 17 & 147 & 69 & 63 & 57 & 2 & 29 & 231 & 57 & 545 & 65 \\
\hline Oxacillin & 78 & 18 & 5 & 31 & 1 & 9 & 26 & 54 & 43 & 20 & 32 & 29 & 1 & 14 & 108 & 27 & 186 & 22 \\
\hline Methicillin & 27 & 6 & 0 & 0 & 0 & 0 & 15 & 31 & 56 & 26 & 24 & 22 & 0 & 0 & 95 & 23 & 122 & 14 \\
\hline Cephalothin & 0 & 0 & 0 & 0 & 0 & 0 & 1 & 2 & 4 & 2 & 11 & 10 & 0 & 0 & 16 & 4 & 16 & 2 \\
\hline Fosfomycin & 70 & 16 & 0 & 0 & 8 & 73 & 32 & $6 \overline{7}$ & 36 & $1 \overline{7}$ & 73 & 66 & 2 & 29 & 151 & 37 & 221 & 26 \\
\hline Tetracycline & 81 & 19 & 3 & 19 & 3 & 27 & 10 & 21 & 120 & 56 & 40 & 36 & 2 & 29 & 178 & 44 & 259 & 31 \\
\hline Chloramphenicol & 9 & 2 & 1 & 6 & 0 & 0 & 3 & 6 & 23 & 11 & 22 & 20 & 0 & 0 & 49 & 12 & 58 & 7 \\
\hline Erythromycin & 35 & 8 & 4 & 25 & 0 & 0 & 7 & 15 & 38 & 18 & 30 & 27 & 0 & 0 & 79 & 19 & 114 & 14 \\
\hline Lincomycin & 40 & 9 & 5 & 31 & 0 & 0 & 7 & 15 & 32 & 15 & 24 & 22 & 1 & 14 & 69 & 17 & 109 & 13 \\
\hline Gentamicin & 0 & 0 & 0 & 0 & 0 & 0 & 0 & 0 & 0 & 0 & 5 & 5 & 0 & 0 & 5 & 1 & 5 & 1 \\
\hline Nitrofurantoin & 21 & 5 & 0 & 0 & 0 & 0 & 0 & 0 & 0 & 0 & 3 & 3 & 0 & 0 & 3 & 1 & 24 & 3 \\
\hline Co-trimoxazole & 31 & 7 & 1 & 6 & 0 & 0 & 0 & 0 & 39 & 18 & 12 & 11 & 0 & 0 & 52 & 13 & 83 & 10 \\
\hline
\end{tabular}

$\mathrm{U}=$ unidentified.

Numbers in parentheses indicate number of isolates in each group. 
incidence of resistance was higher among nonlyogroup I than among lyogroup I isolates, with increases from 1.5 times for oxacillin to 6 times for chloramphenicol. None of the isolates resistant to cephalothin or gentamicin was in lyogroup I. The incidence of resistance was higher among lyogroup I than among non-lyogroup I isolates for penicillin and nitrofurantoin only. All of the five gentamicinresistant isolates encountered in this study belonged to lyogroup VI, and of the 24 nitrofurantoinresistant isolates, 21 belonged to lyogroup I and three to lyogroup VI. A high overall antibiotic sensitivity was shown by lyogroup III, which agrees with what has been reported elsewhere for Staph. capitis. ${ }^{9}$ On the other hand, the greatest incidence of fosfomycin-resistance was found within this lyogroup. Lyogroups V and VI were, on the whole, the most resistant to antibiotics.

With regard to the open question whether an in-depth or limited discrimination within the genus Staphylococcus is preferable in clinical bacteriology, ${ }^{32}$ our findings suggest that a rather precise discrimination is desirable. Preliminary indications of certain lyogroup- (or species-) specific antimicrobial susceptibility patterns and associations with particular infection sites advise against $a$ priori limiting the identification of staphylococcal species or lyogroups. A real knowledge of the epidemiology and pathological significance of each particular Staphylococcus species or lyogroup will be possible only if accurate identification of the isolate is the rule in diagnostic laboratories. Routinely performed species separation within other genera of pathogenic organisms is recommended for similar reasons. On the other hand, practical and rapid identification of staphylococci, such as that obtained with our simplified lyogroup method, can be performed routinely even in poorly equipped diagnostic laboratories.

\section{References}

1 Torres Pereira A. Coagulase-negative strains of staphylococcus possessing antigen 51 as agents of urinary infection. J Clin Pathol 1962;15:252-3.

${ }^{2}$ Mitchell RG. Staphylococci and urinary infections. Br Med J 1965;i:1127.

${ }^{3}$ Mabeck CE. Significance of coagulase-negative staphylococcal bacteriuria. Lancet 1969 ;ii:1150-2.

4 Bailey RR. Significance of coagulase-negative staphylococcus in urine. J Infect Dis 1973;127:179-82.

${ }^{5}$ Maskell R. Importance of coagulase-negative staphylococci as pathogens in the urinary tract. Lancet 1974 ; : 1155-8.

${ }^{6}$ Digranes A, Oeding P. Characterization of Micrococcaceae from the urinary tract. Acta Pathol Microbiol Scand Sect B 1975;83:373-81.

' Meers PD, Whyte W, Sandys G. Coagulase-negative staphylococci and micrococci in urinary tract infections. $J$ Clin Pathol 1975;28:270-3.

${ }^{8}$ Williams DN, Lund ME, Blazevic DJ. Significance of urinary isolates of coagulase-negative Micrococcaceat. $J$ Clin Microbiol 1976;3:556-9.

- John JE Jr, Gramling PK, O'Dell NM. Species identification of coagulase-negative staphylococci from urinary tract isolates. J Clin Microbiol 1978;8:435-7.

${ }^{10}$ Satta G, Varaldo PE, Grazi G, Fontana R. Bacteriolytic activity in staphylococci. Infect Immun 1977;16:37-42.

11 Varaldo PE, Satta G, Grazi G, Romanzi CA. Grouping of staphylococci on the basis of their bacteriolytic-activity patterns: a new approach to the taxonomy of the Micrococcaceae. I. Identification of six different "lyogroups". Int J Sist Bacteriol 1978;28:141-7.

12 Varaldo PE, Satta G. Grouping of staphylococci on the basis of their bacteriolytic-activity patterns: a new approach to the taxonomy of the Micrococcaceae. II. Main characters of 1,054 strains subdivided into "lyogroups". Int J Syst Bacteriol 1978;28:148-53.

${ }^{13}$ Satta G, Varaldo PE. Tenca M, Radin L. The relevance of bacterial lytic activity in the taxonomy of the Micrococcaceae: failure of its production by Micrococcus and Planococcus as opposed to Staphylecoccus. J Gen Microbiol 1978;109:385-8.

1 Varaldo PE, Satta G, Hájek V. Taxonomic study of coagulase-positive staphylococci: bacteriolytic activity pattern analysis. Int J Syst Bacteriol 1978;28:445-8.

15 Varaldo PE, Grazi G. Soro O. Cisani G, Satta G. Simplified lyogroup system, a new method for routine identification of staphylococci: description and comparison with three other methods. J Clin Microbiol 1980;12: 63-8.

16 Varaldo PE, Grazi G, Cisani G, Satta G. Routine separation of staphylococci from micrococci based on bacteriolytic activity production. J Clin Microbiol 1979;9: 147-8.

17 Satta G, Grazi G, Varaldo PE, Fontana R. Detection of bacterial phosphatase activity by means of an original and simple test. J Clin Pathol 1979;32:391-5.

18 Branson D. Identification of Micrococcaceae in clinical bacteriology. Appl Microbiol 1968;16:906-11.

19 Raymond EA, Traub WG. Identification of staphylococci isolated from clinical material. Appl Microbiol 1970;19: 919-22.

${ }^{20} \mathrm{~K}$ loos WE, Musselwhite MS. Distribution and persistence of Staphylococcus and Micrococcus species and other aerobic bacteria on human skin. Appl Microbiol 1975: 30:381-95.

${ }^{21}$ Cisani G. PhD Thesis, University of Genoa, 1977.

${ }^{22}$ Holt R. The classification of staphylococci from colonized ventriculoatrial shunts. $J$ Clin Pathol 1969;22:475-82.

${ }^{23}$ Andriole VT, Lyons RW. Coagulase-negative staphylococcus. Ann NY Acad Sci 1970;174:533-44.

${ }^{24}$ Drach GW. Problems in diagnosis of bacterial prostatitis: gram-negative, gram-positive and mixed infections. J Urol 1974;111:630-6.

${ }^{25}$ Mortensen N. Studies in urinary tract infections. III. Biochemical characteristics of coagulase-negative staphylococci associated with urinary tract infections. Acta Med Scand 1969;186:47-51.

${ }^{26}$ Nord CE, Holta-Öie S, Ljungh A, Wadström T. Characterization of coagulase-negative staphylococcal species from human infections. Zentralbl Bakteriol Parasitenk Infektionskr Hyg Abt 1 1976;Suppl 5:105-11.

27 Hovelius B, Mardh PA. On the diagnosis of coagulasenegative staphylococci with emphasis on Staphylococcus saprophyticus. Acta Pathol Microbiol Scand Sect B 1977; $85: 427-34$

${ }^{28}$ Namayar F, de Graaff J, MacLaren DM. Micrococci and urinary infection. Lancet $1977 ; \mathbf{i i}: 1223-4$.

${ }^{29}$ Oeding P, Digranes A. Classification of coagulasenegative staphylococci in the diagnostic laboratory. 
Acta Pathol Microbiol Scand Sect B 1977;85:136-42.

${ }^{30}$ Marsik FJ, Parisi JT. Significance of Staphylococcus epidermidis in the clinical laboratory. Appl Microbiol $1973 ; 25: 11-4$

${ }^{31}$ Sabath LD, Barrett FF, Wilcox C, Gerstein DA, Finland M. Methicillin resistance of Staphylococcus aureus and Staphylococcus epidermidis. Antimicrob Agents Chemother $1968 ; 302-6$

${ }^{32}$ Subcommittee on the Taxonomy of Staphylococci and
Micrococci. Minutes of the Meeting, 9 September 1975. Appendix 1, Identification of staphylococci. Int $J$ Syst Bacteriol 1976;26:332-4.

Requests for reprints to: PE Varaldo, MD, Istituto di Microbiologia dell' Università di Genova, Medical School, Viale Benedetto XV, 10, 16132 Genova, Italy.

\section{Reports and Bulletins prepared by the Association of Clinical Biochemists}

The following reports and bulletins are published by the Association of Clinical Biochemists. They may be obtained from The Publishing Department, British Medical Journal (ACB Technical Bulletins), BMA House, Tavistock Square, London WC1H 9JR. Overseas readers should remit by British Postal or Money Order.

SCIENTIFIC REVIEIVS (price $£ 1 \cdot 00 / \$ 2.00$ each)

1 The assessment of thyroid function March 1971 FV FLYNN and JR HOBBS

2 Renal function tests suitable for clinical practice January 1972 FL MITCHELL, N VEALL, and RWE WATTS

3 Biochemical tests for the assessment of fetoplacental function May 1975 CE WILDE and RE OAKEY

4 Test of exocrine pancreatic function March 1977 AH GOWENLOCK

5 Assay of cholinesterase in clinical chemistry March 1979 ELSIE SILK, J KING, and MARY WHITTAKER

TECHNICAL BULLETINS (price $£ 1 \cdot 00 / \$ 2.00$ each)

22 Bilirubin standards and the determination of bilirubin by manual and technicon AutoAnalyzer methods January 1971 BARBARA BILLING, RUTH HASLAM, and N WALD

23 Interchangeable cells for spectrophotometers and fluorimeters September 1971 SS BROWN and AH GOWENLOCK

24 Simple tests to detect poisons March 1972 BW MEADE et al.

\section{Blood gas analysers May 1972 K DIXON}

26 Kits for enzyme activity determination September 1972 SB ROSALKI and D TARLOW

27 Assessment of pumps suitable for incorporation into existing continuous flow analytical systems November 1972 A FLECK et al.

28 Routine clinical measurements of transferrin in human serum September 1973 K DIXON
29 Control materials for clinical biochemistry (5th edition) September 1973 JF STEVENS

30 Notes on the quality of performance of serum cholesterol assays September 1973 sS BROWN

31 Determination of uric acid in blood and in urine July 1974 RWE WATTS

32 A survey of amino acid analysers readily available in the United Kingdom September 1974 JE CARLYLE and P PURKIss

33 Definitions of some words and terms used in automated analysis November 1974 A FLECK, R ROBINSON, SS BROWN, and JR HOBBS

34 Measurement of albumin in the sera of patients January 1975 LINDA SLATER, PM CARTER, and JR HOBBS

35 Investigation of the validity of temperature correction factors for serum aspartate and alanine transaminases March 1975 SB ROSALKI et al.

36 Factors influencing the assay of creatinine November 1975 JGH COOK

37 A survey of enzyme reaction rate analysers readily available in the United Kingdom July 1977 RA SAUNDERS and RF BURNS

38 Transport of specimens for clinical chemistry analysis November 1977 P WILDING, JF ZILVA, and CE WILDE

39 A scheme for the evaluation of diagnostic kits May 1978 PH LLOYD

40 A practical guide to gamma-counting in radioimmunoassay January 1980 CE WILDE and D OTTEWELL

41 The use of biochemical tests in the diagnosis of disorders of calcium metabolism July 1980 ANGELA FAIRNEY 